\title{
English PBL teaching model research in the era of internet+
}

\author{
Guo Zhe \\ Foreign Language College of BeiHua University, Jilin, China
}

Keywords: Internet + age; College English; PBL teaching mode

\begin{abstract}
With the introduction of modern information technology with the computer and network as the core into the field of education, it not only brings the innovation of education technology, but also provides a condition for the transition of the teaching mode. This paper at first analyzes the challenges that the era of internet+ brings to college English teaching and discusses the necessity of college English teaching with PBL teaching mode. On this basis, the further research focuses on the implementation method, the implementation process, the evaluation of the effect after the implementation of PBL teaching mode and the requirements of PBL teaching mode for college English teachers in the era of internet+. PBL teaching mode makes effective use of what the information network era have entrusted to college English teaching, improves the effect of classroom teaching, makes up for the shortage of the college English teaching mode in the past and provides a strong guarantee for the improvement of college students' English level.
\end{abstract}

\section{Introduction}

With the further development of internet technology and the increasing frequency of international communication, English communicative competence under the background of cross-cultural communication has become one of the essential abilities of the modern college students.

Higher Education Department issued the "College English Curriculum Requirements" in July 2007, in which it is explicitly pointed out that the institutions of higher learning should make full use of modern information technology, adopt the computer classroom English teaching mode and improvement the single teaching mode giving priority to teacher. The new teaching pattern should take the modern information technology, especially network technology as the support and make teaching and learning of English not limited by time and place in a certain extent and develop towards the direction of individualized and autonomous learning. The new English teaching mode should reflect the principle of combining practical, informative and interesting teaching, which is helpful to arouse the enthusiasm of teachers and students and especially reflects students' subject status in the process learning and teachers' leading role in the process of teaching. PBL is a kind of new teaching mode, which is very different from traditional teaching methods. In the traditional teaching mode, what teachers simply teach is knowledge, and students only passively accept the knowledge teachers teach in class. The traditional English teaching mode with teachers' teaching as the center only aims to cultivate the test ability of the students, but students' language application ability and language communication ability are very limited. In the application of PBL teaching mode under the network environment, English teaching and learning in a certain extent can be integrated as a whole, which is helpful to arouse the enthusiasm of teachers and students and can realize the optimization of English teaching. 


\section{The opportunities and challenges that college English teaching is facing in the era of Internet+}

Internet refers to the international information on the Internet, mainly including communication network, computer, database and daily electronic products, which is a rich electronic information exchange system. "Internet+" is the new format in the innovation of internet development, the morphological evolution of internet driven by the social knowledge innovation and a new form of the economic and social development. "Internet+" is the further practice achievement of internet thinking, which can promote economic form to evolve unceasingly, thus promote the vitality of social economic entity and provide broad network platform for reform, innovation and development. Therefore, internet not only provides new methods for ideological and cultural communication, but also provides a new approach for college English learning. In addition, the fast communication of internet enables college English teaching to keep up with the latest development of English education and eliminate the deficiencies of the traditional college English teaching materials. Internet teaching materials have a large amount of information and interactive network resources, which can change the deficiency of traditional college English teaching in the lack of information and teaching material.

Many colleges and universities set up a large number of college English learning websites and can use FTP file upload and download the related files to university English learning. The international college English teaching "camp” established through internet builds a good college English learning atmosphere and provides a rare development opportunity for college English teaching. However, opportunities and challenges coexist. Internet also brings challenge to college English teaching. At first, internet breaks through the limit of time and space so as to make college English teaching have a broad space and time. How to effectively establish innovative teaching modes with advanced network technology and how to improve college students' English application ability on the basis of college English teaching are the present problem that college English teachers are faced with and also the challenges that the advanced internet technology brings to college English teachers. Secondly, the English learning materials on internet are almost the latest information. The control of information is in the hands of college students themselves, which is to a great extent based on the need to assign and requires college students to have a higher ability to study independently. Finally, internet technologies provide a lot of English learning information for college students, at the same time, the information is also mixed with some useless resources inevitably, which is more likely to be the wrong argument, therefore, it can be challenge for college students to be capable of identifying information and make correct use of information.

\section{The theoretical basis and development of PBL teaching mode}

PBL teaching theory is based on Piaget's constructivist learning theory. Constructivism is also known as structuralism, which is a branch of cognitive theory. Constructivism believes that learning is not a passive process of absorption, practice and memory strengthening, but based on students' existing knowledge and experience. It is a process actively constructing "meaning" through the individual and the environment interaction. PBL is based on information processing psychology and cognitive psychology, which belongs to the category of constructivism learning theory. Constructivism teaching reform is a widely adopted in the vision of thinking.

The basic idea of PBL teaching is to set learning in a complicated and meaningful problem environment, enabling learners to acquire the implicit scientific knowledge at the back of the problem, form problem solving skills and cultivate their own lifelong learning ability through 
solving the problem of authenticity in cooperation. In 1969, American professor of neurology Barrows in Mc Master University of Canada firstly put trial use of PBL teaching mode. This kind of teaching mode was used in the school of medicine in Harvard University years later and gradually received recognition and affirmation from the educational circles in the United States. Someone even called it "the most appropriate developing model for school administrators". Since then, PBL teaching by its unique superiority has achieved significant results and rapidly promoted in the whole world in foreign teaching mode reform, becoming a more and more widely valued teaching mode internationally in recent years. According to the WHO report, at present there are about more than 1700 global medical schools using PBL teaching mode, and the number is still growing. In China, the mode was introduced by the Shanghai Second Medical University and Xi 'an Medical University in 1986, taking the lead in the introduction of PBL teaching at home. Then, more and more domestic colleges and universities introduced the teaching mode. The research of PBL teaching is becoming more in-depth and also increasingly mature in theory. So colleges started to try using PBL teaching mode in the other fields and achieved good results.

In college English teaching, the goal of college English teaching is to cultivate high-quality professional and technical personnel with a higher level of English. College English teaching focuses on improving college students' use of English professional knowledge and the ability of foreign exchange, requires college students to have a solid basic knowledge of English, especially the ability to use the knowledge of English to deal with practical problems. At present, many college students after several years of English study have acquired and mastered certain English language knowledge, but lack of practical ability of English integrated application. Traditional way of college English teaching takes English teaching as the center, so college students remain in the position of the passive obedience. This traditional teaching mode basically fails to consider the individual difference of college students and can't make college students' subjective initiative into full play. The PBL teaching mode pays more attention to "student-centered" teaching, emphasizes the importance of college students' active learning and self-study and make college students develop clear goals in the process of learning. It is needless to say that the introduction of this teaching model is beneficial to college English.

\section{PBL teaching mode based on the analysis of Internet+}

(I) The implementation of the PBL teaching mode in network era

1. The student-centered and teachers auxiliary learning. PBL teaching mode under the network era will transform the traditional teacher-centered way of learning to student-centered way of learning, fully mobilizing the students' learning initiative. Teacher acts as an auxiliary role in classroom teaching and build a relaxed and active learning atmosphere for the students, which can increase the efficiency of college English learning, build the atmosphere to use English to communicate and improve the comprehensive use of college students' English ability.

2. Discussion-based learning group. Under the guidance of PBL teaching mode in the network era, English teachers on the one hand guide students according to English teaching materials and the related data, on the other hand adopt the teaching mode of discussion-based learning in groups. Teachers can at first map out a certain topic with several titles given to students, then students choose titles according to the topic they're personally interested in, use their spare time to consult a lot of English literature through the network, form text material after group discussion, make speeches as is determined by the group leader of students in the classroom and make additional ideas, etc. This procedure allows other groups to ask English questions and then carry out classroom discussion or debate. The college students spend a lot of energy to refer to the related useful 
information to the topic they choose on internet, which is far more than the energy they spend on ordinary classroom learning. Therefore, PBL teaching needs college students to have strong ability of autonomous learning.

3. The students' autonomous evaluation and mutual evaluation. PBL teaching mode in the network age should constantly reform examination content, examination form and exam achievement evaluation method. Every achievement includes not only English teacher evaluation results, but also assessment performance in each group. The test can take both written and oral forms. That is to say, the overall achievement in English includes two parts: written and oral English scores, increasing the proportion of the grade at ordinary times and enabling students with poor English level to be likely to rely on their every progress in order to get the final overall achievement. Students' achievement is not completely determined by their scores in final exam, which can increase students' learning interest and learning enthusiasm.

(II) The implementation of PBL teaching mode under the network environment

Through comprehensively analyzing the PBL teaching mode currently applied in different areas, combined with the actual situation of college English teaching, teaching practice process elements are divided into setting problem situation, comprehensive analysis problem situation, summarization and discussion, and analysis and evaluation.

\section{Setting problem situation}

PBL teaching mode in network era takes problems as the beginning of the study. It is the main factor to determine the PBL teaching effect how and what to design the problems. Problem setting is determined by the subject in English teaching material. Teachers should set the contents of the teaching material as problems and design a variety of different problems, mainly adopting the following several aspects:

(1) English play. English teachers should inspire college students to transform English text into script and prepare for English drama performance. Students should take advantage of competition in the form of performance.

College students can actively prepare their performance in different groups and expect to achieve good effect in each performance. Thus, students are not only familiar with the content of the text, but also improve their English level of speaking and listening.

(2) Debate

Many texts in college English teaching material such as “The Right Son at the Right time” are great subject of debate. Students are required to sum up the idea of the author, analyze its rationality and compare with personal understanding. According to different personal understanding, they carry out debate.

(3) Situation report

Students should use the websites English teachers give to learn related knowledge points related to the problems and form their own point of view. The teacher then arranges each group prepare for and present situation report in the classroom.

(4) Classroom import.

Before teachers instruct the content in English teaching material, they can arrange an assignment to let all students help to design classroom import.

(5) Exercise

Teachers should require students to find English news every day through the Internet and then adapt the English information collected as cloze, reading comprehension and listening. Different teams can exchange questions and practice mutually, which can arouse the students' interest in learning English and improve the students' ability to use English. 
Above problem setting forms are beneficial to cultivating college students "question consciousness” and innovative thinking, making college students' not only learn English language knowledge easily, but also be familiar with the social, historical and environmental knowledge related to human survival. In the process of using network technology to seek answers to questions, students improve their consciousness of independent learning, self-study ability and interpersonal communication and cooperation ability.

2. Analysis to solve the problem situation.

Because the problem is complex, teachers should often ask students to participate in unity and cooperation is groups as group English learning is the best way to study under the network environment. Group cooperation is also one of the main characteristics of PBL teaching mode.

In networked learning environment, college student is not only an individual of independent learning, but also a member to participate in learning activities more broadly. Group members analyze and solve the problems with the method of group discussion.

In addition, each group members has different division of labor, so each college student should be clear of his own tasks. Then, each of the group members makes a lot of researches according to their tasks and sum up information of all aspects in the problem solving process.

3. Summarization and discussion.

After teacher has assigned problems and carried on the clear division of labor for each member in different groups, every college student must collect information according to their own tasks. Then, they use the network chatting to communicate, research and implement network information resource sharing and cooperatively to complete the task.

(III) PBL implementation effect evaluation

Evaluation is a critical part in PBL teaching mode of network era. Evaluation can be used to test students' learning status, provide timely and accurate feedback to college students. In the process of dealing with problems, developing dynamic evaluation model should be taken advantage of. English learning itself is a phase with dynamic change, corresponding to the PBL teaching mode under the network environment. College English teaching should change the teaching evaluation mode in the past and make full use of the advantages of network: instant feedback, management convenience, time saving and efficiency improvement, etc., to make tracking monitoring, examination and management in the whole process of college English teaching, pay more attention to process evaluation and develop formative assessment.

In order to establish a new, dynamic and interactive mode of evaluation, it is necessary to reflect the characteristics of network in personalization, multimedia and network. There are various evaluation ways of PBL in network environment, including college students' self-evaluation, English teachers' evaluation, evaluation from personnel outside the group and evaluation from professional teachers. The following table is student assessment analysis.

Table. 1 Questions in student assessment

\begin{tabular}{|l|l|l|l|l|}
\hline Interview content & Yes & No & Percentage & Advice \\
\hline $\begin{array}{l}\text { (1) Do you think PBL teaching content with } \\
\text { your learning goals }\end{array}$ & & & & \\
\hline $\begin{array}{l}\text { (2) Are your satisfied with the implementation } \\
\text { of PBLL teaching in college English teaching? }\end{array}$ & & & & \\
\hline $\begin{array}{l}\text { (3) Do you think the course schedule } \\
\text { reasonable? }\end{array}$ & & & \\
\hline $\begin{array}{l}\text { (4) What do you think of strengths and } \\
\text { weaknesses of PBL teaching method? }\end{array}$ & & & \\
\hline
\end{tabular}




\begin{tabular}{|l|l|l|l|l|}
\hline $\begin{array}{l}\text { (5) Through PBL study, has it made an impact } \\
\text { on your learning method? }\end{array}$ & & & & \\
\hline $\begin{array}{l}\text { (6) Through the implementation of the PBL } \\
\text { teaching method, do you think of your interest in } \\
\text { learning is enhanced? }\end{array}$ & & & & \\
\hline $\begin{array}{l}\text { (7) Do you think group discussions has raised } \\
\text { your ability in learning, planning, } \\
\text { communication and cooperation? }\end{array}$ & & & & \\
\hline (8) Can you adapt to the PBL teaching? & & & & \\
\hline $\begin{array}{l}\text { (9) What aspects of PBL teaching method in the } \\
\text { process of implementation are needed to } \\
\text { improve do you think? }\end{array}$ & & & & \\
\hline
\end{tabular}

\section{Conclusion}

Although PBL teaching mode in the network age has become a great challenge to English teachers and college students, this kind of teaching mode can effectively increase the students' study enthusiasm and cultivate college students' English comprehensive application ability.

\section{Reference}

[1] Barrows H S. A Taxonomy of Problems-based Learning Methods[J].Med Education, 1986, 20(6): 481-486.

[2]Yang Yan, Zhong Xiaohong. College English PBL teaching mode research [J]. Chengdu Univ TCM (Education science), 2013(2):9-10.

[3]Wen Qiufang. The challenge and countermeasures for college English: curriculum theory perspective [J]. Foreign Language Teaching and Research, 2012, (2): 283-292. 